\title{
Postharvest Handling Recommendations for Cut Pineapple Lily
}

\author{
Alicain S. Carlson ${ }^{1}$ and John M. Dole
}

AdDitional INDEX wORDs. Eucomis, sucrose pulses, preservatives, hydrator, holding solution

SUMMARY. The effects of various postharvest treatments on cut stems of 'Coral' and 'Sparkling Burgundy' pineapple lily (Eucomis sp.) were evaluated to determine best postharvest handling practices. The use of a commercial hydrator, holding solution, or both significantly reduced vase life for 'Coral'; the deionized (DI) water control had the longest vase life. 'Sparkling Burgundy' vase life was significantly reduced to 29.9 days when both a commercial hydrator and holding solution were used as compared with 50.3 days when DI water was the hydrator used with the commercial holding solution. The use of a bulb-specific preservative reduced vase life of 'Coral' to 43.8 days, while the DI water control had a vase life of 66.4 days, and commercial holding solution was intermediate at $\mathbf{5 6 . 8}$ days. A $\mathbf{1 0 \%}$ sucrose pulse reduced vase life to 46.9 days compared with the $0 \%$ sucrose control ( 58.9 days) and the $20 \%$ sucrose concentration (62.5 days), which were not significantly different. The use of floral foam and/or $2 \%$ or $4 \%$ sucrose concentrations plus isothiazolinone reduced vase life significantly to an average of 11.1 days. The vase life of stems cold stored at $2{ }^{\circ} \mathrm{C}$ for 1 week (37.7 days) was not significantly different from the unstored stems (43.0 days), while longer storage times up to 3 weeks significantly reduced vase life. The use of hydrating solution pretreatments before and holding solution treatments during 4 days of cold storage had no significant effect on vase life. 'Sparkling Burgundy' stems harvested with $100 \%$ of the florets open had the longest vase life of 51.2 days compared with 38.4 days when $1 \%$ of the florets were open. Vase life was unaffected by exogenous ethylene exposure up to $1 \mathrm{ppm}$ for 16 hours. For best postharvest quality, 'Coral' and 'Sparkling Burgundy' pineapple lily should be harvested when at least $50 \%$ of the florets are open, held in plain water without preservatives, and stored for no more than 1 week (wet or dry) at $2{ }^{\circ} \mathrm{C}$.

$\mathrm{N}$ ew cut flower introductions are a necessity to maintain and increase consumer interest. Expanding the availability and knowledge of new cut flowers allows growers to pick species ideally suited for their climate and consumer preferences. Many exotic, bulbous genera and cultivars, such as pineapple lily, are underused by the floral industry. From South Africa, the genus Eucomis has $\approx 15$ species (Bryan and Griffiths, 1995), each with pineapple-like inflorescences that have the potential to last for more than 1 month in a vase (Clark et al., 2010). Growers are hesitant to produce new crops without information on postharvest techniques that maximize postharvest quality.

Department of Horticultural Science, North Carolina State University, Campus Box 7609, Raleigh, NC 27695

We gratefully acknowledge funding by ICFG/Hill Foundation and Gloeckner Foundation, plant material from a commercial bulb producer and support from the floriculture research technicians, Ingram McCall and Diane Mays, as well as Erin Clark, Brigitte Crawford, and Benjamin Brindis.

${ }^{1}$ Corresponding author. E-mail: ascarlso@ncsu.edu.
A number of factors influence vase life after harvest, including ethylene, storage temperatures, sucrose pulses, and commercial preservatives. Ethylene exposure can have deleterious effects on cut flowers causing petal, floret, and leaf abscission, failure of buds to open, epinasty, and rapid senescence (Dole and Wilkins, 2005; Reid, 1989). The ethylene sensitivity of cut pineapple lily is unknown.

Cooling retards the utilization of carbohydrates during respiration, which extends postharvest life and delays development in most species (Sacalis and Seals, 1993). A desirable quality of a cut flower is the ability to be shipped long distances out of water (dry) without an adverse effect on vase life. Despite the benefits of cold and dry storage, some flower species do not respond well (Sacalis and Seals, 1993).

Pretreatments are used to extend vase life and are applied before holding in floral preservatives (Hunter, 2000). Sucrose pulses are a pretreatment used to increase vase life by loading stems with sugar to facilitate the storage of carbohydrates before they are dry packed and shipped long distances or held in storage for long periods of time (Hunter, 2000; Nowak and Rudnicki, 1990). Effective concentrations depend on the species and can have variable effects (Mohan Ram and Ramanuja Rao, 1977), but generally range anywhere from $1 \%$ to $20 \%$ (Dole and Wilkins, 2005). Sucrose treatments should also include a biocide to prevent bacterial growth (Hunter, 2000).

Commercial preservatives extend the vase life of many species but may have no effect on others (Sacalis and Seals, 1993). Typically, floral preservatives can be categorized as either hydrating, holding, or vase solutions. Holding solutions contain a carbohydrate source to encourage bud opening, flower longevity, or both and are applied for $\approx 1-2 \mathrm{~d}$. Some holding solutions have been specifically formulated to be beneficial to bulb species. Hydrating solutions are meant to be applied before a holding solution right after harvest for about $4 \mathrm{~h}$ to facilitate water uptake and do not contain a carbohydrate source (Dole, 2011). Vase solutions are applied by the consumer and contain a higher concentration of carbohydrates than a holding solution (Dole, 2011). 'Sparkling Burgundy' pineapple lily (Fig. 1A) was found to have the greatest vase life ( $43 \mathrm{~d}$ ) in tap water; the use of preservative solutions significantly shortened vase life

\begin{tabular}{llll}
\hline $\begin{array}{l}\text { Units } \\
\begin{array}{l}\text { To convert U.S. } \\
\text { to SI, multiply by }\end{array}\end{array}$ & U.S. unit & SI unit & $\begin{array}{l}\text { To convert SI } \\
\text { to U.S., multiply by }\end{array}$ \\
\hline 10 & $\%$ & $\mathrm{~g} \cdot \mathrm{L}^{-1}$ & 0.1 \\
0.3048 & $\mathrm{ft}$ & $\mathrm{m}$ & 3.2808 \\
2.54 & $\mathrm{inch}(\mathrm{es})$ & $\mathrm{cm}$ & 0.3937 \\
1 & $\mathrm{mmho} / \mathrm{cm}$ & $\mathrm{dS} \cdot \mathrm{m}^{-1}$ & 1 \\
0.001 & $\mathrm{ppm}$ & $\mathrm{g} \cdot \mathrm{L}^{-1}$ & 1000 \\
1 & $\mathrm{ppm}$ & $\mathrm{mg} \cdot \mathrm{L}^{-1}$ & 1 \\
0.001 & $\mathrm{ppm}$ & $\mathrm{mL} \cdot \mathrm{L}^{-1}$ & 1000 \\
1 & $\mathrm{ppm}$ & $\mu \mathrm{L} \cdot \mathrm{L}^{-1}$ & 1 \\
$\left({ }^{\circ} \mathrm{F}-32\right) \div 1.8$ & ${ }^{\circ} \mathrm{F}$ & ${ }^{\circ} \mathrm{C}$ & $\left({ }^{\circ} \mathrm{C} \times 1.8\right)+32$
\end{tabular}


(Clark et al., 2010). The ability for new cut flowers to perform well in floral foam is also important, especially to floral designers.

The objectives of this study were to determine postharvest handling recommendations for optimum vase life of cut pineapple lily using 'Coral' (Fig. 1B) and 'Sparkling Burgundy', by examining several postharvest procedures and solutions, including commercial preservatives, ethylene sensitivity, sucrose pulses, and cold storage.

\section{Materials and methods}

Plant material. Bulbs of 'Coral' pineapple lily were received from a commercial supplier on 14 May 2009 and held overnight. 'Sparkling Burgundy' bulbs were dug and divided from field beds at North Carolina State University. Bulbs were all planted on 15 May 2009 and grown in either a double-layered polyethylene plastic-covered greenhouse or loamy clay soil field beds $(3 \times 180 \mathrm{ft})$ in Raleigh, NC. In the greenhouse, bulbs were planted in lily crates $(22 \times$ $14.5 \times 9$ inches) using a commercial peat-based root substrate (Fafard $4 \mathrm{P}$ Mix; Fafard, Agawam, MA) and grown at $20 \pm 5{ }^{\circ} \mathrm{C}$ night temperatures and ambient air temperatures during the day. In the greenhouse, plants were fertigated with $250 \mathrm{ppm}$ nitrogen $(\mathrm{N})$ from a premixed commercial $20 \mathrm{~N}-4.4 \mathrm{P}-16.6 \mathrm{~K}$ fertilizer

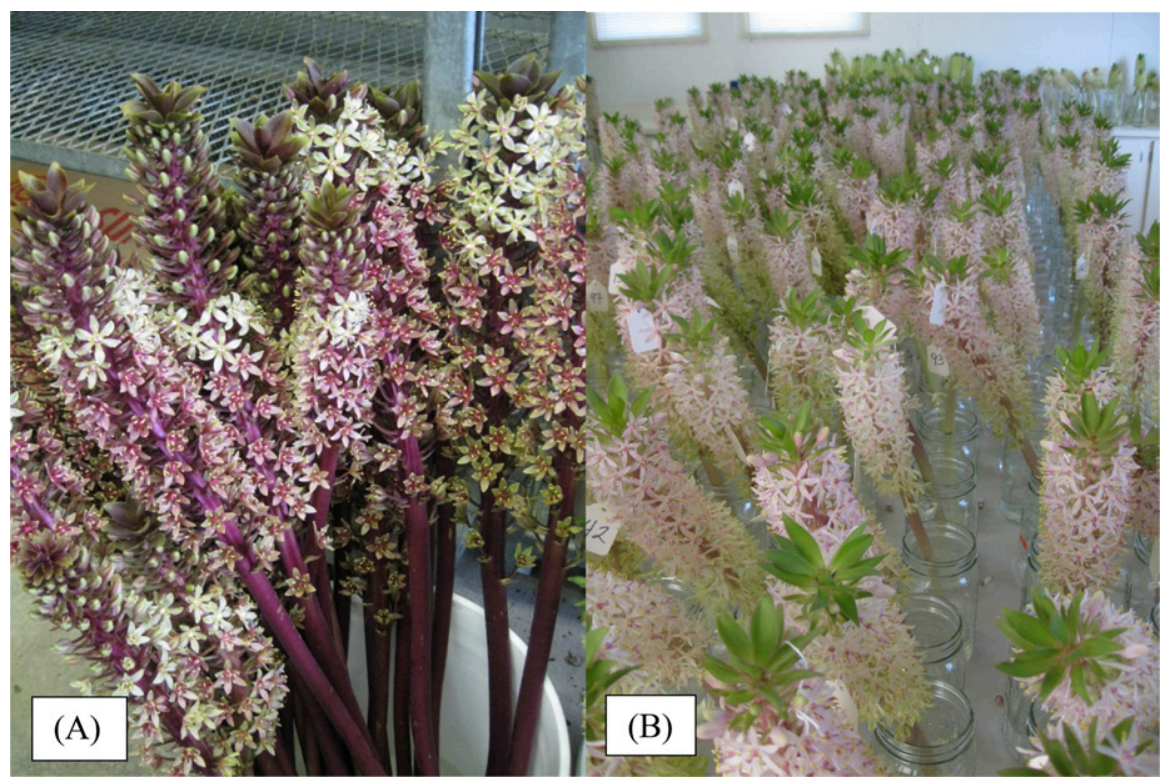

Fig. 1. (A) Cut 'Sparkling Burgundy' pineapple lily inflorescences; (B) cut 'Coral' pineapple lily inflorescences.

(Peter's, Allentown, PA) during the week and irrigated with clear water on the weekends.

Postharvest handling. Inflorescences were harvested when at least $25 \%$ to $75 \%$ of the florets were open, except for the harvest stage experiment, placed in tap water $[0.21$ $\mathrm{d} S \cdot \mathrm{m}^{-1}$ electrical conductivity (EC), $6.1 \mathrm{pH}]$, recut after hydrating for $\approx \mathrm{l} \mathrm{h}$, and sorted by degree of openness into the treatments outlined below. All commercial preservative solutions were used at manufacturer recommended concentrations. Stems from the two different production locations were evenly sorted into treatments for the commercial preservative experiments. After treatment, all stems were placed into vases of deionized water $\left(0.00 \mathrm{dS} \cdot \mathrm{m}^{-1} \mathrm{EC}, 4.4 \mathrm{pH}\right)$ with one stem per vase until termination unless otherwise noted. Stems were held in a postharvest environment at $21 \pm 2{ }^{\circ} \mathrm{C}$ air temperature under $20 \mu \mathrm{mol} \cdot \mathrm{m}^{-2} \cdot \mathrm{s}^{-1}$ light for $12 \mathrm{~h} \cdot \mathrm{d}^{-1}$ at $40 \%$ to $60 \%$ relative humidity ( $\mathrm{RH})$ until termination. A stem was considered ready to terminate when $50 \%$ of the florets had either wilted or desiccated or the stem bent past a $90^{\circ}$ angle. A completely randomized design was used with 11 to 15 stems per treatment; treatments were arranged in a factorial where appropriate. Each set of treatments included a DI water control. Vase life and termination symptoms (necrotic stem, bent stem, and desiccated florets/buds) were recorded for each set of experiments.

Commercial preservatives. Cut stems of field and greenhousegrown 'Coral' and 'Sparkling Burgundy' were placed into hydrating solution $\left(8 \mathrm{~mL} \cdot \mathrm{L}^{-1}\right.$ Floralife Hydraflor 100; Floralife, Walterboro, SC) or DI water for $4 \mathrm{~h}$ and then placed in either holding solution $\left(10 \mathrm{~mL} \cdot \mathrm{L}^{-1}\right.$ Floralife Professional) or DI water for $2 \mathrm{~d}$. 'Coral' was harvested when $\approx 25 \%$ of the florets were open and 'Sparkling Burgundy' was harvested when $25 \%$ to $75 \%$ of the florets were open on a stem.

BULB-SPECIFIC PRESERVATIVES. Stems of field-grown 'Coral' were held in DI water for $4 \mathrm{~h}$ and then held in either bulb-specific holding solution (10 $\mathrm{g} \cdot \mathrm{L}^{-1}$ Floralife Bulb Flower Food), holding solution (10 $\mathrm{mL} \cdot \mathrm{L}^{-1}$ Floralife Professional), or DI water for $2 \mathrm{~d}$.

Cold storage duration. Cut stems of field-grown 'Coral' were held for 1,2 , or 3 weeks at $2 \pm 2{ }^{\circ} \mathrm{C}$ and $65 \%$ to $75 \% \mathrm{RH}$ either dry packed in floral boxes lined with newspaper or wet in buckets of DI water. Stems were recut when taken out of storage.

ETHYLENe SENSITIVITY. Cut stems of field-grown 'Coral' were placed into 55-gal sealed steel drums and subjected to $0,0.1$, or $1.0 \mathrm{ppm}$ ethylene for $16 \mathrm{~h}$.

Harvest stage. Cut stems of field-grown 'Sparkling Burgundy' were harvested at five different stages of openness: $\approx 5 \%, 25 \%, 50 \%, 75 \%$, or $100 \%$ of the florets open.

Pretreatments and storage. Cut stems of field-grown 'Coral' were pretreated for $4 \mathrm{~h}$ with one of three solutions: hydrating solution 1 (8 $\mathrm{mL} \cdot \mathrm{L}^{-1}$ Floralife Hydraflor 100), hydrating solution $2\left(2 \mathrm{~mL} \cdot \mathrm{L}^{-1}\right.$ Chrysal Professional 1; Chrysal, Miami, FL), or DI water then held for $4 \mathrm{~d}$ at $2 \pm$ $2{ }^{\circ} \mathrm{C}$ and $65 \%$ to $75 \% \mathrm{RH}$ in one of four holding treatments: holding solution $1\left(10 \mathrm{~mL} \cdot \mathrm{L}^{-1}\right.$ Floralife Professional), holding solution 2 (10 $\mathrm{mL} \cdot \mathrm{L}^{-1}$ Chrysal Professional 2), DI water, or dry packed in floral boxes lined with newspaper. Stems were recut when taken out of storage.

Sucrose pulses. Cut stems of field-grown 'Coral' were treated with a 24 -h pulse of $0 \%, 10 \%$, or $20 \%$ sucrose in DI water plus 7 ppm isothiazolinone (Kathon CG; Rohm \& Haas, Philadelphia, PA). 
VASE SOLUTIONS AND SUBSTRATES. Cut stems of greenhouse-grown 'Coral' were placed in vases with $7 \mathrm{ppm}$ isothiazolinone, with or without floral foam (Instant Deluxe floral foam; Smithers-Oasis Co., Cuyahoga Falls, $\mathrm{OH}$ ) and either $0 \%, 2 \%$, or $4 \%$ sucrose until termination.

Statistical analysis. Data were analyzed using analysis of variance using the General Linear Models procedure with vase as the experimental unit and means separated by Tukey's multiple comparison procedure at $P \leq$ 0.05 using SAS (version 9.3, SAS Institute, Cary, NC).

\section{Results}

COMMERCIAL PRESERVATIVES $(\mathrm{N}=$ 15). Hydrating and holding solution interacted to influence the vase life of 'Coral' and 'Sparkling Burgundy' (Table 1 ). The use of a commercial hydrator or holding solution significantly reduced vase life for 'Coral'. 'Coral' was prone to stem weakening causing it to bend past a $90^{\circ}$ angle resulting in its termination. 'Sparkling Burgundy' vase life was significantly reduced to 29.9 d when both a commercial hydrator and holding solution were used as compared with $50.3 \mathrm{~d}$ when DI water was the hydrator used with the commercial holding solution. 'Sparkling Burgundy' stems harvested from the greenhouse had a longer vase life, $48.2 \mathrm{~d}$, than those from the field, $37.6 \mathrm{~d}$. Production location had no significant effect on vase life of 'Coral'. There were no significant interactions between postharvest treatment and production location for both cultivars.

BULB-SPECIFIC PRESERVATIVE $(\mathrm{N}=$ 15). The bulb-specific holding solution had the shortest vase life of 43.8 $\mathrm{d}$, the DI water control had the longest vase life of $66.4 \mathrm{~d}$, and the commercial holding solution was intermediate at $56.8 \mathrm{~d}$.

COld STORAge DURATION $(\mathrm{N}=$ 15). Stems stored for two or three weeks had a significantly reduced vase life of 18.8 and $19.6 \mathrm{~d}$, respectively, compared with the unstored control of $43.0 \mathrm{~d}$. The vase life of stems stored for one week ( $37.7 \mathrm{~d})$ was not significantly different from the unstored stems. There was no significant difference in vase life whether stems were stored wet or dry.
ETHYLENe SENSITIVITy $(\mathrm{N}=15)$. Ethylene exposure did not affect vase life and averaged $63.7 \mathrm{~d}$.

Harvest STAGe $(\mathrm{N}=13)$. As the percent of open florets on 'Sparkling Burgundy' increased, vase life increased. When stems were harvested with $100 \%$ of the florets open, vase life was $51.2 \mathrm{~d}$ and when $5 \%$ were open, vase life was $38.4 \mathrm{~d}$ (Fig. 2).

Pretreatments and Storage $(\mathrm{N}=15)$. There was no significant difference among hydrating and holding/cold storage treatments. The average vase life was $66.3 \mathrm{~d}$. There were no significant interactions.

SuCrOSE PULSES $(\mathrm{N}=\mathbf{1 5})$. A $10 \%$ sucrose pulse significantly reduced vase life to 46.9 d from 58.9 d for $0 \%$ sucrose and $62.5 \mathrm{~d}$ for the $20 \%$ sucrose concentration, which all included isothiazolinone. The $0 \%$ and $20 \%$ concentrations were not significantly different. The DI water control had a vase life of $66.6 \mathrm{~d}$.

VASE SOLUTIONS AND SUBSTRATES $(\mathrm{N}=1 \mathbf{1})$. The DI water control resulted in the longest vase life of

Table 1. The effect of preservative solutions on vase life of 'Coral' and 'Sparkling Burgundy' pineapple lily. 'Coral' was harvested when $\approx \mathbf{2 5 \%}$ of the florets were open and 'Sparkling Burgundy' was harvested when $25 \%$ to $75 \%$ of the florets were open. Greenhouse and field-grown stems were placed into a hydrating solution [Hydrator (Floralife Hydraflor 100; Floralife, Walterboro, SC)] or deionized (DI) water for $4 \mathrm{~h}$ followed by either holding solution [Holding (Floralife Professional)] or DI water for $2 \mathrm{~d}$ then placed into vases of DI water until termination. Means are an average of 15 stems.

\begin{tabular}{lllc}
\hline Cultivar & Hydrator & Holding & Vase life (d) \\
\hline Coral & Water & Water & $17.9 \mathrm{a}^{\mathrm{z}}$ \\
& & Holding & $9.8 \mathrm{~b}$ \\
& Hydrator & Water & $9.4 \mathrm{~b}$ \\
& & Holding & $6.3 \mathrm{~b}$ \\
Significance & & 0.0013 \\
Sparkling Burgundy & Water & Water & $48.5 \mathrm{ab}$ \\
& & Holding & $50.3 \mathrm{a}$ \\
& Hydrator & Water & $43.0 \mathrm{ab}$ \\
Significance & & Holding & $29.9 \mathrm{~b}$ \\
& & & 0.0414
\end{tabular}

${ }^{z}$ Means followed by the same letter within cultivar are not significantly different according to Tukey's multiple comparison procedure at $\alpha=0.05$.

'Probability values were obtained using General Linear Models (GLM) procedures of SAS (version 9.3, SAS Institute, Cary, NC).

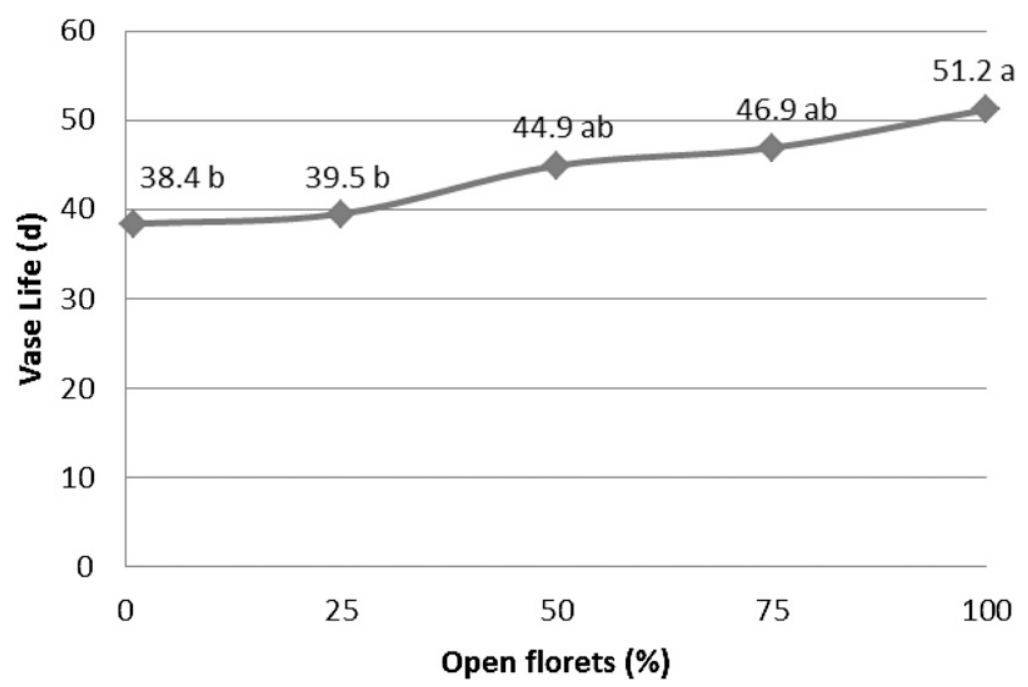

Fig. 2. Effect of harvest stage (percent of open florets) on vase life of 'Sparkling Burgundy' pineapple lily. Cut stems of field-grown 'Sparkling Burgundy' were harvested at five different stages of openness: $\approx 5 \%, 25 \%, 50 \%, 75 \%$, or $100 \%$ of the florets open and then placed into jars of deionized water until termination. Means with the same letters are not significantly different according to Tukey's multiple comparison procedure at $P \leq 0.05$ using SAS (version 9.3, SAS Institute, Cary, NC). 
$64.3 \mathrm{~d}$. The use of floral foam and/or low sucrose concentrations plus isothiazolinone reduced vase life significantly to an average of $11.1 \mathrm{~d}$. There were no significant interactions.

\section{Discussion}

The longest average vase life observed in any one treatment was an exceptional $66.6 \mathrm{~d}$ from a DI water control solution for 'Coral'. 'Sparkling Burgundy' had a maximum average vase life of $51.2 \mathrm{~d}$ when it was harvested with $100 \%$ of the florets open. For the majority of common cut flower species, this length of postharvest life is very rare. DI water consistently resulted in the longest vase life when compared with other vase solution treatments. However, in the commercial preservatives experiment with 'Coral', the DI water control had an average vase life of just $17.9 \mathrm{~d}$ because of the stems losing turgidity and bending over resulting in their termination. This was the first experiment performed in this series, which resulted in the use of stems that were at an earlier stage of harvest closer to $25 \%$ open rather than a range of $25 \%$ to $75 \%$, which were evenly sorted into the treatments for subsequent experiments. Typically, spike-type inflorescences are recommended to be harvested when at least $25 \%$ to $30 \%$ of the florets are open (Armitage et al., 2003; Dole and Wilkins, 2005), but we found from the stage of harvest experiment with 'Sparkling Burgundy' that the stems harvested with more open florets last longer. This trend is highly likely to continue in other cultivars of pineapple lily including 'Coral'. However, even though the harvest stage was not ideal the data still show that a preservative does not need to be used with 'Coral' to extend vase life. Additionally, preservatives specifically formulated for bulbous species further reduced vase life of 'Coral'. Further, a $20 \%$ sucrose pulse resulted in an insignificant increase in vase life over the DI water control, while the $10 \%$ concentration significantly shortened vase life. The reason for this difference with the sucrose concentrations is not clear. The $2.2 \mathrm{~d}$ increase in vase life when a holding solution was used on 'Sparkling Burgundy' is not significant enough for most producers and wholesalers to justify the cost of preservatives. Clark et al. (2010) found vase life to be significantly reduced to $10.6 \mathrm{~d}$ when the same commercial hydrating and holding solutions were used on 'Sparkling Burgundy'. On the basis of the results of these various studies, it is not recommended to use floral preservatives, including sucrose solutions, with 'Coral' or 'Sparkling Burgundy' pineapple lily. The use of floral preservatives should be tested with other cultivars of pineapple lily as there may be cultivar differences.

While cold storage of cut stems of 'Coral' pineapple lily is not optimum, it may be necessary and should be limited to no more than 1 week at $2{ }^{\circ} \mathrm{C}$ to maintain vase life. In addition, pretreatments with hydrating and holding solutions did not improve vase life of 'Coral' after $4 \mathrm{~d}$ of cold storage. However, slightly higher storage temperatures should be tested to see if pineapple lily would be more tolerant to longer storage durations, which would improve its commercial potential and extend the season of availability. Pineapple lily may be similar to some tropical species that cannot tolerate very low storage temperatures, such as anthurium (Anthurium $\times$ cultorum), which should be stored at $13{ }^{\circ} \mathrm{C}$ to avoid chilling injury (Sacalis and Seals, 1993).

Vase life was severely shortened by floral foam. A possible reason for the decline in vase life could be that the particular foam used might have restricted water uptake through the stem by being too dense. Floral foam is designed to absorb water evenly and hold stems in place for floral designs, but water release depends on the density of the foam. Inserting the fleshy stem into the dense foam could have caused damage to the vasculature, thereby limiting water uptake, which may have caused the loss of turgidity. There are alternative formulations of floral foams that are less dense that may be more appropriate. Even with the statistically significant reduction in vase life, it was still long enough to be considered acceptable for short-term event floral designs.

Greenhouse production of 'Sparkling Burgundy' resulted in an $\approx 10 \mathrm{~d}$ increase in vase life compared with field-grown stems, while there was no significant difference for 'Coral'. The differences could have been related to several different preharvest production factors, such as nutrient and water availability in the substrate, day and night temperatures, light levels, or humidity (Slootweg, 2005; Torre et al., 2001; Twumasi et al., 2005)

Pineapple lily's extensive vase life may be partially due to its insensitivity to up to l ppm exogenous ethylene and would make it an excellent cut flower for growers that also produce fruits and vegetables as long as ethylene rates do not exceed the tested $1 \mathrm{ppm}$ for $16 \mathrm{~h}$. Additionally, harvesting stems at later stages when at least $50 \%$ of the florets are open may be beneficial because of increased carbohydrate storage in the stem allowing an energy source for the last $50 \%$ of buds to open and seed pods to develop that add to the visual appeal of the inflorescence. The inflorescence is very fleshy and has a thick cuticle layer that may also contribute to its extensive vase life by reducing water loss through transpiration.

\section{Conclusion}

For best postharvest quality, 'Coral' and 'Sparkling Burgundy' pineapple lily should be harvested when at least $50 \%$ of the florets are open, held in plain water, and stored for no more than 1 week at $2{ }^{\circ} \mathrm{C}$. However, vase life is acceptable even when preservatives are used allowing it to be mixed into bouquets with flowers that benefit from preservatives. While there are likely to be cultivar differences, this work provides growers and wholesalers with acceptable general recommendations until more cultivars are evaluated. Pineapple lily has many positive qualities that would appeal to growers, wholesalers, and consumers, including extensive vase life, up to 1 week of cold storage (wet or dry at $2^{\circ} \mathrm{C}$ ), ethylene insensitivity (up to $1 \mathrm{ppm}$ ), and no need for preservative solutions.

\section{Literature cited}

Armitage, A.M., J.M. Laushman, and P. Dugan. 2003. Specialty cut flowers, the production of annuals, perennials, bulbs, and woody plants for fresh and dried cut flowers. Timber Press, Portland, OR.

Bryan, J. and M. Griffiths. 1995. Manual of bulbs. Timber Press. Portland, OR. 
Clark, E.M.R., J.M. Dole, A.S. Carlson, E.P. Moody, I.F. McCall, F.L. Fanelli, and W.C. Fonteno. 2010. Vase life of new cut flower cultivars. HortTechnology 20:1016-1025.

Dole, J.M. 2011. Maintaining postproduction quality, p. 463-487. In: P.V. Nelson (ed.). Greenhouse operation and management. 7th ed. Pearson, New York, NY.

Dole, J.M. and H.F. Wilkins. 2005. Floriculture: Principles and species. 2nd ed. Prentice Hall, Upper Saddle River, NJ.

Hunter, N.T. 2000. The art of floral design. Thomson Delmar Learning, Clifton Park, NY.
Mohan Ram, H.Y. and I.V. Ramanuja Rao. 1977. Prolongation of vase-life of Lupinus hartwegii Lindl. by chemical treatments. Sci. Hort. 7:377-382.

Nowak, J. and R.M. Rudnicki. 1990. Postharvest handling and storage of cut flowers, florist greens, and potted plants. Timber Press, Portland, OR.

Reid, M.S. 1989. The role of ethylene in flower senescence. Acta Hort. 261: 157-169.

Sacalis, J.N. and J.L. Seals. 1993. Cut flowers: Prolonging freshness: Postproduction care and handling. 2nd ed. Ball Publ., Batavia, IL.
Slootweg, G. 2005. Effects of greenhouse conditions on the quality and vase life of freesia 'Yvonne'. A nursery comparison. Acta Hort. 669:297-301.

Torre, S., T. Fjeld, and H.R. Gislerød. 2001. Effects of air humidity and $\mathrm{K} / \mathrm{Ca}$ ratio in the nutrient supply on growth and postharvest characteristics of cut roses. Sci. Hort. 90:291-304.

Twumasi, P., W. van Ieperen, E.J. Woltering, A.M.C. Emons, J.H.N. Schel, J.F.H. Snel, U. van Meeteren, and D. van Marwijk. 2005. Effects of water stress during growth on xylem anatomy, xylem functioning, and vase life in three Zinnia elegans cultivars. Acta Hort. 669:303-311. 